\title{
Recent Catalyst Technology Development in Residue Catalytic Cracking Unit: A Mini Review
}

\author{
Suhendra ${ }^{a, 1, *}$, Zen Adi Laksana ${ }^{\mathrm{a}, 2}$, Dhenok Widiastuti ${ }^{\mathrm{a}, 3}$, Tita Griya Melyta ${ }^{\mathrm{a}, 4}$ \\ ${ }^{a}$ Chemical Engineering Department, Faculty of Industrial Technology, Universitas Ahmad Dahlan, Tamanan, Banguntapan, Bantul, \\ Yogyakarta 55164 \\ ${ }^{1}$ suhendra@ che.uad.ac.id *; ${ }^{2}$ zen1600020073@webmail.uad.ac.id $;{ }^{3}$ dhenok1600020077@webmail.uad.ac.id; ${ }^{4}$ tita1600020083@webmail.uad.ac.id \\ * corresponding author
}

\section{ARTICLE INFO}

\section{Article history}

Received December 05, 2019

Revised December 21, 2019

Accepted December 23, 2019

\section{Keywords}

Catalyst

Fuel

Residue

Regeneration

RCC Technology

\begin{abstract}
AB STRACT
The use of fuel oil from year to year until now has experienced a rapid increase, due to increasing population growth in vehicle operations and the development of industries that require fuel. The position of renewable energy has not been able to shift the position of petroleum fuels to the needs of the world market. The RCC unit is secondary processing that converts heavy fraction hydrocarbons to light fraction hydrocarbons with the help of using catalysts into high-value petroleum products such as Naphtha, LPG, and Light Cycle Oil. RCC unit has three main parts of the process, namely riser, stripper, and regenerator, with the use of the main raw material of residue and using a catalyst. This paper aims at reviewing recent journals concerning the catalyst applied in the RCC unit. The basis of the RCC unit to be reviewed is from an existing RCC unit in Indonesia. The development of research on catalysts and regeneration technology in the RCC unit has experienced rapid development until now. It is expected that this paper can contribute to the future development and application of catalysts for the RCC unit, both for national and international levels.
\end{abstract}

This is an open access article under the CC-BY-SA license.

\section{Introduction}

Fuels consist of petroleum fuels and renewable energy. The need for petroleum fuels has increased rapidly along with population growth. And the position of renewable energy is still not able to shift the position of fuel oil which becomes an energy source and still dominates the availability in the world market [1]. Figure 1 shows the estimate consumption world's energy needed.

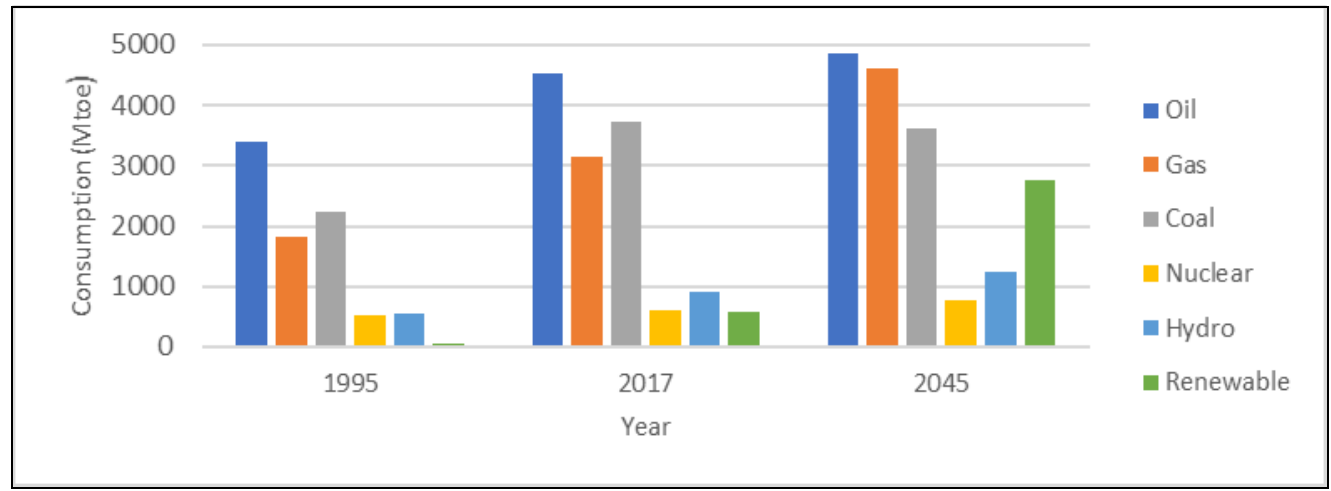

Fig. 1. Estimation of the world's energy needs according to BP-Energy Outlook 2019 
Referring to Figure 1, fuels consist of petroleum fuels and renewable energy. The need for fuel oil in Indonesia will continue to increase until 2050 with an estimated increase of 40.1\% from 4,569 million BOE [2]. Therefore, to optimize and maximize the production of petroleum fuels, one of them is by utilizing residue, which is a by-product into a more valuable petroleum product by using the Residue Catalytic Cracking Unit [3].

Residue Catalytic Cracking (RCC) is secondary industrial processing that converts heavy fraction hydrocarbons to lighter fraction hydrocarbons into more valuable petroleum products. The RCC unit consists of three main parts namely riser, stripper, and regenerator. In the RCC process, heavy oil experiences direct contact with the catalyst at high temperatures. Then, the output from the reactor is further processed in the column to be separated according to the type of oil product based on its boiling point, which will produce kind of light oil and heavy oil. Then catalyst after used will be fell into the stripper and after this flowed to the top of the regenerator with the aim to reactivate the catalyst by removing coke attached to the catalyst surface and regenerated by combustion of coke attached to the catalyst [4].

Until now the development of residue catalytic cracking technology continues, especially the development of catalyst types and regeneration technology. Catalysts used in the RCC process are various, but generally use zeolite catalysts [5], synthetic silica-alumina, natural composites or aluminosilicates, and silica aluminate [6]. However, most of the commercial catalytic cracking processes use catalysts of silica-alumina and zeolite [7]. Then catalyst will be recycling with regeneration technology using a regenerator, with the aim to reactivate the catalyst by removing coke attached to the catalyst surface [8].

\section{Thermodynamic Study of Catalytic Cracking Reaction}

In this paper, the thermodynamic study of catalytic cracking reaction is based on an available theory of quantum chemical calculation. Quantum chemical calculation. is a method that is generally used in the field of chemical research, with high accuracy results for chemical reactions [9]. Quantum chemical calculations through Density Functional Theory (DFT) are used to estimate the thermodynamic reaction parameters of the refinery oil process, modeling of the structure of catalyst materials, investigating the mechanism of substance formation on the catalyst surface and the stage of forming transition parts (which describe the adsorption hydrocarbons in different natural catalysts) various pore geometries, etc.) [10]. The reference data shows that the value calculated by the DFT method is more reliable for the reaction of isoparaffin cracking, isomerization of paraffin, olefin, and aromatics cracking, and naphthene dealkylation. The molecular model created in the Gauss View software and presented in Figure 2 (as an example of the paraffin hydrocarbon cracking reaction).

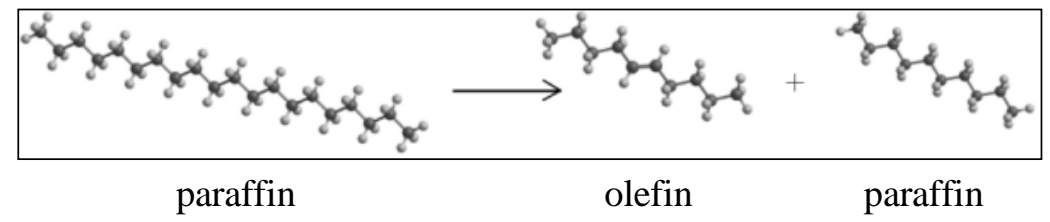

Fig. 2. The reaction of paraffin cracking Gauss View

Table 1 shows the thermodynamic parameters that have the possibility of catalytic cracking reactions of thermodynamics according to the results calculated using the DFT method. Paraffin reactivity in an endothermic cracking reaction is increased by increasing the molecular weight of $n$ paraffin. Paraffin reactivity in an endothermic cracking reaction is increased by increasing the molecular weight of $\mathrm{n}$-paraffin. The value of Energy Gibbs change is $\Delta \mathrm{G}=-42.8 \mathrm{~kJ} / \mathrm{mol}$ for cracking $\mathrm{C}_{5}-\mathrm{C}_{11}$ paraffin and $\Delta \mathrm{G}=-77.4 \mathrm{~kJ} / \mathrm{mol}$ for cracking from $\mathrm{C}_{14}-\mathrm{C}_{40}$ paraffin. $\mathrm{C}_{5}-\mathrm{C}_{11+}$ isoparaffin cracking reaction from a thermodynamic point of view $(\Delta \mathrm{G}=-56.7 \mathrm{~kJ} / \mathrm{mol})$, then the normal hydrocarbon cracking structure is $(\Delta \mathrm{G}=-42.8 \mathrm{~kJ} / \mathrm{mol})$.

The endothermic reaction of dealkylation and cracking of naphthenes is characterized by high thermodynamic probabilities $(\Delta \mathrm{G}=-145.5 \mathrm{~kJ} / \mathrm{mol}$ and $\Delta \mathrm{G}=-186.5 \mathrm{~kJ} / \mathrm{mol})$ comparison with dealkylation of aromatic hydrocarbons $(\Delta \mathrm{G}=-91.6 \mathrm{~kJ} / \mathrm{mol})$. At the same time, the dealkylation of aromatic hydrocarbons with less molecular weight (aromatic from the gasoline fraction) is ( $\Delta \mathrm{G}=$ - 
$84.0 \mathrm{~kJ} / \mathrm{mol})$. The reaction of hydrogen transfers and aromatization $(\Delta \mathrm{G}=-162.0 \mathrm{~kJ} / \mathrm{mol}$ and $\Delta \mathrm{G}=-$ $137.0 \mathrm{~kJ} / \mathrm{mol}$ ) possible thermodynamics under process conditions and hydrogen transfer of the reaction are written through the next few steps. The aromatic hydrocarbon phase and the formation of isoparaffins from olefins and naphthene are the most likely thermodynamic, because of the naphthenic structure due to their high aroma [11].

Table 1. Thermodynamic Parameters of Catalytic Cracking Reaction

\begin{tabular}{|c|c|c|}
\hline Reaction & $\Delta \mathrm{H}, \mathrm{kJ} / \mathrm{mol}$ & $\Delta \mathrm{G}, \mathrm{kJ} / \mathrm{mol}$ \\
\hline \multicolumn{3}{|l|}{ Primary Cracking } \\
\hline \multicolumn{3}{|l|}{ Cracking of n-paraffins $\mathrm{C}_{14-\mathrm{C}_{40}}$} \\
\hline $\mathrm{C}_{20} \mathrm{H}_{44} \rightarrow \mathrm{n}-\mathrm{C}_{10} \mathrm{H}_{22}+\mathrm{C}_{10} \mathrm{H}_{20}$ & 64.2 & -77.4 \\
\hline $\begin{array}{c}\mathrm{C}_{20} \mathrm{H}_{44} \rightarrow \mathrm{i}-\mathrm{C}_{10} \mathrm{H}_{22}+\mathrm{C}_{10} \mathrm{H}_{20} \\
\text { Naphthene Dealkylation }\end{array}$ & 64.8 & -66.4 \\
\hline $\begin{array}{c}\left(\mathrm{C}_{10} \mathrm{H}_{21}\right)_{2}-\mathrm{C}_{6} \mathrm{H}_{4} \rightarrow \mathrm{C}_{6} \mathrm{H}_{10}+2 \mathrm{C}_{10} \mathrm{H}_{20} \\
\text { Aromatic Dealkylation }\end{array}$ & 142.4 & -145.5 \\
\hline $\begin{array}{c}\left(\mathrm{C}_{10} \mathrm{H}_{21}\right)_{2}-\mathrm{C}_{6} \mathrm{H}_{4} \rightarrow \mathrm{C}_{6} \mathrm{H}_{6}+2 \mathrm{C}_{10} \mathrm{H}_{20} \\
\text { Naphthene Cracking }\end{array}$ & 155.9 & -91.6 \\
\hline$\left(\mathrm{C}_{7} \mathrm{H}_{15}\right)_{2}-\mathrm{C}_{10} \mathrm{H}_{16} \rightarrow \mathrm{C}_{8} \mathrm{H}_{17}-\mathrm{C}_{6} \mathrm{H}_{5}+2 \mathrm{C}_{10} \mathrm{H}_{20}+2 \mathrm{H}_{2}$ & 248.3 & -186.5 \\
\hline \multicolumn{3}{|l|}{ Secondary Cracking } \\
\hline \multicolumn{3}{|l|}{ Isomerization of n-paraffin $\mathrm{C}_{5}-\mathrm{C}_{11+}$} \\
\hline \multicolumn{3}{|l|}{ Cracking of Isoparaffin $\mathrm{C}_{5}-\mathrm{C}_{11+}$} \\
\hline \multicolumn{3}{|l|}{ Cracking of Olefin $\mathrm{C}_{5}-\mathrm{C}_{11+}$} \\
\hline $\mathrm{C}_{7} \mathrm{H}_{14} \leftrightarrow \mathrm{C}_{2} \mathrm{H}_{4}+\mathrm{C}_{5} \mathrm{H}_{10}$ & 93.4 & -31.1 \\
\hline \multicolumn{3}{|l|}{ Hydrogen Transfer } \\
\hline $\mathrm{C}_{6} \mathrm{H}_{10}+\mathrm{C}_{6} \mathrm{H}_{12} \leftrightarrow \mathrm{C}_{6} \mathrm{H}_{6}+\mathrm{i}-\mathrm{C}_{6} \mathrm{H}_{14}$ & -85.5 & -38.2 \\
\hline $\mathrm{C}_{6} \mathrm{H}_{10}+\mathrm{C}_{6} \mathrm{H}_{12} \rightarrow \mathrm{C}_{6} \mathrm{H}_{6}+\mathrm{i}-\mathrm{C}_{6} \mathrm{H}_{14}$ & -169.7 & -162.0 \\
\hline \multicolumn{3}{|l|}{ Condensation } \\
\hline $\mathrm{C}_{2} \mathrm{H}_{3}-\mathrm{C}_{6} \mathrm{H}_{5}+\mathrm{C}_{8} \mathrm{H}_{16} \rightarrow \mathrm{C}_{10} \mathrm{H}_{6}-\left(\mathrm{C}_{3} \mathrm{H}_{7}\right)_{2}+2 \cdot \mathrm{H}_{2}$ & -5.0 & -77.3 \\
\hline $\mathrm{C}_{2} \mathrm{H}_{3}-\mathrm{C}_{6} \mathrm{H}_{5}+\mathrm{C}_{8} \mathrm{H}_{16} \rightarrow \mathrm{C}_{10} \mathrm{H}_{6}-\left(\mathrm{C}_{3} \mathrm{H}_{7}\right)_{2}+2 . \mathrm{H}_{2}$ & -28.7 & -120.4 \\
\hline \multicolumn{3}{|l|}{ Coke } \\
\hline $\mathrm{C}_{10} \mathrm{H}_{8} \rightarrow 5 . \mathrm{C}_{24} \mathrm{H}_{12}+18 . \mathrm{H}_{2}$ & 114.0 & -623.7 \\
\hline
\end{tabular}

\section{Brief Description of RCC Plant Process}

Figure 3 shows the process scheme for the existing RCC units in Indonesia. Referring to Figure 3 , the RCC feeds at stream 1, namely atmospheric residue (AR) and vacuum residue that will be contacted to the reactor, using lift steam and lift gas. Cracking reaction occurs in the reactor riser with operating conditions $485^{\circ} \mathrm{C}-540{ }^{\circ} \mathrm{C}\left(900{ }^{\circ} \mathrm{F}-1000{ }^{\circ} \mathrm{F}\right)$ and pressures up to 100 psi [6].

A stream 2, the catalyst contacts with oil and accelerates the cracking reaction, besides the catalyst will provide heat to the hydrocarbons so that it accelerates the cracking reaction that occurs. The catalyst and hydrocarbons rise to the top of the riser with the help of a steam elevator and gas lift. After the saturation reaction occurs at the top of the riser (reactor) it will produce long-chain paraffin, the catalyst must be separated from the hydrocarbons to reduce the thermal cracking 
process so that the hydrocarbon chains become smaller and eventually will cause the formation of coke. The product of the cracking reaction in the form of hydrocarbons will then separate from the catalyst and fall into the stripping section.

A stream 4 , the results of the top product in the form of hydrocarbons will go out into the fractionation column to be separated. Separating hydrocarbons into overhead vapor, which will produce a light fraction fuel in the form of naphtha, LCO, HCO, and DCO, based on its boiling point. A stream 5, take advantage of the material to be refluxed and separated again, while stream 6 will produce a light oil fraction in the form of naphtha [12].

A stream 7, the catalyst collected in the stripper will be flowed to the top of the regenerator with the aim to reactivate the catalyst by removing coke attached to the catalyst surface and regenerated by combustion of coke attached to the catalyst by contacting stream 8 in the form of air. In the upper regenerator, partial combustion occurs where the coke will be burned to produce $\mathrm{CO}$ to $\mathrm{CO} 2$. A stream 9, the CO-containing fuel gas exits the upper regenerator through the cyclone to be separated from the remnants of the catalyst [8].

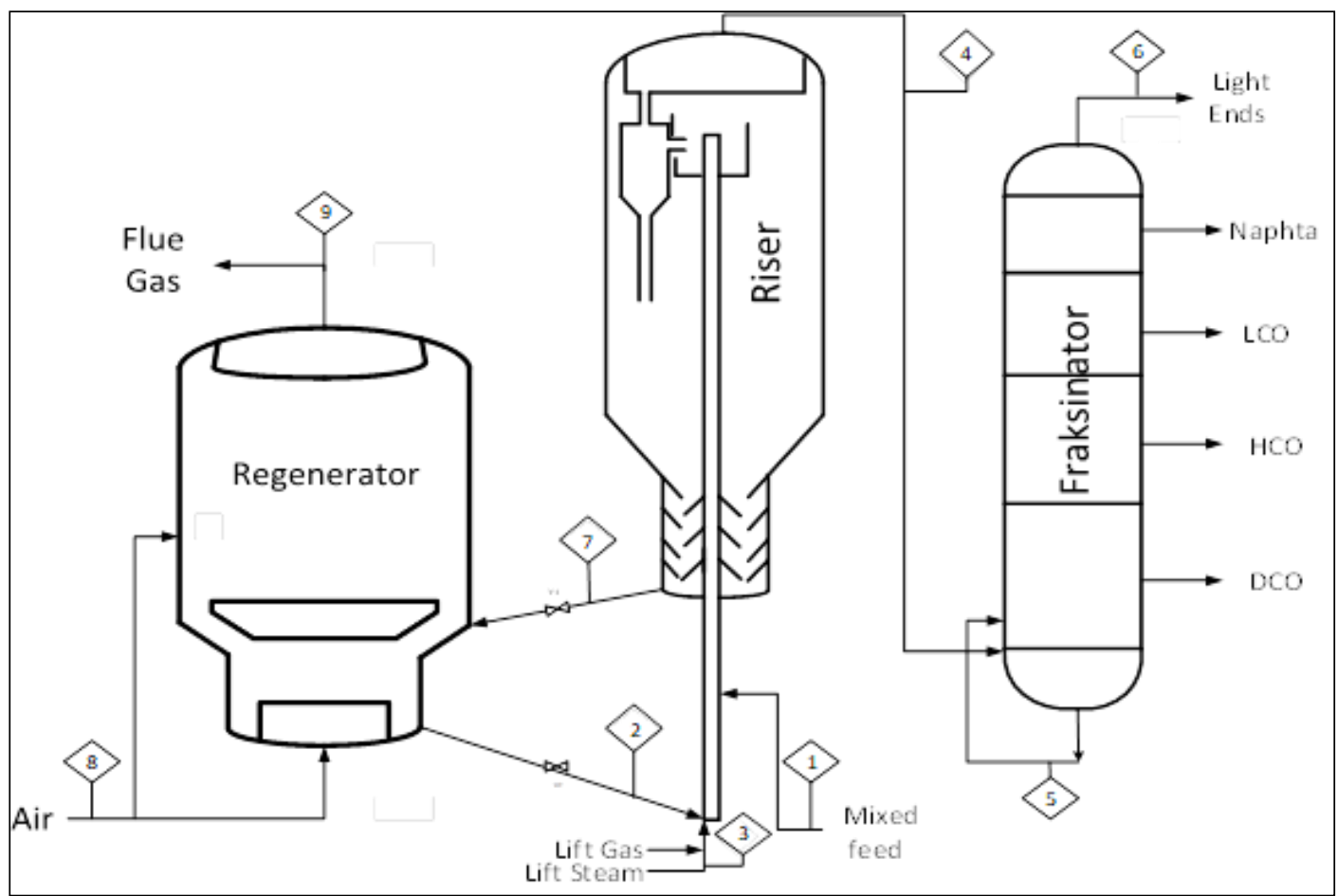

Fig. 3. RCC Plant Unit

\section{The Catalyst of Residue Catalytic Cracking}

One of the challenges in choosing a catalyst is that the metal contained in the feed is continuously deposited on the catalyst, causing the deactivation of the catalyst. To prevent deactivation, the catalyst must have a high tolerance to deposited metals. Another challenge is the high level of coke formed by high boiling residual feeds, so the regenerator must be well designed and the catalyst must have high hydrothermal stability and the ability to withstand high regenerator temperatures [13]. Therefore, catalysts that have suitable activities, high gasoline selectivity, and catalyst stability are very important in this process $[14,15]$. The catalyst used is usually in the form of microspheres, spheres, and other performed forms [7].

The catalyst used in the RCC process generally uses zeolite catalysts [5], synthetic silicaalumina, natural composites or aluminosilicates, and silica aluminate [6]. But most of the commercial catalytic cracking process is carried out using silica alumina and zeolite catalysts type [7]. Even so, research on catalysts in the process of catalytic cracking residues continues to grow until now such as the development of zeolite catalysts [5, 16], catalysts of metal oxide nanoparticles [17], zirconia catalysts impregnated in red mud [18, 19], and rare earth catalyst [20, 21]. Table 2 
shows the variates of catalysts and feeds for the RCC unit equipped with the operation condition and conversion value.

Table 2. Residue Catalytic Cracking Catalyst

\begin{tabular}{|c|c|c|c|c|c|c|}
\hline Catalyst & $\mathbf{T}$ & $\mathbf{P}$ & Feed & Reactor & Conversion & Reference \\
\hline E-Cat/ZSM-5 & $650{ }^{\circ} \mathrm{C}$ & N/A & Crude Oil & $\begin{array}{l}\text { Fixed-Bed MAT } \\
\text { Unit }\end{array}$ & $60.8 \%$ & {$[22]$} \\
\hline $\mathrm{ZrO}_{2} / \mathrm{MaRM}$ & $500{ }^{\circ} \mathrm{C}$ & $\begin{array}{c}\text { Ambeint } \\
\text { Atmospheric } \\
\text { Pressure }\end{array}$ & $\begin{array}{l}\text { Vacuum } \\
\text { Residue }\end{array}$ & Fixed-Bed Reactor & $79.6 \%$ & [19] \\
\hline $\mathrm{Ni} / \mathrm{K}$ & $440{ }^{\circ} \mathrm{C}$ & 300 psig & $\begin{array}{l}\text { Deasphalted } \\
\text { Vacuum } \\
\text { Residue }\end{array}$ & $\begin{array}{l}\text { Bench-Scale Pilot } \\
\text { Plant Equipped with } \\
\text { an Up-Flow Open } \\
\text { Tubular } \\
\text { Reactor }\end{array}$ & $51.4 \%$ & {$[23]$} \\
\hline $\mathrm{NiK} / \mathrm{MaAl}_{2} \mathrm{O}_{3}$ & \multirow[b]{2}{*}{$500{ }^{\circ} \mathrm{C}$} & \multirow[b]{2}{*}{ N/A } & \multirow{2}{*}{$\begin{array}{l}\text { Vacuum } \\
\text { Residue }\end{array}$} & \multirow[b]{2}{*}{ Fixed-Bed Reactor } & $79.37 \%$ & \multirow[b]{2}{*}{ [24] } \\
\hline $\begin{array}{l}\mathrm{NiK} / 10 \mathrm{CexZr1}- \\
\mathrm{xO}_{2}-\mathrm{MaAl}_{2} \mathrm{O}_{3}\end{array}$ & & & & & $78.66 \%$ & \\
\hline $\begin{array}{l}\text { Ni/Activated } \\
\text { Carbon }\end{array}$ & $400{ }^{\circ} \mathrm{C}$ & $30,1 \mathrm{MPa}$ & $\begin{array}{l}\text { Oil Sand } \\
\text { Bitumen }\end{array}$ & $\begin{array}{c}\text { Batch Auto Clave } \\
\text { Reactor }\end{array}$ & $97.7 \%$ & {$[25]$} \\
\hline $\mathrm{ZrO}_{2} / \mathrm{ARM}$ & $470{ }^{\circ} \mathrm{C}$ & $3 \mathrm{MPa}$ & $\begin{array}{l}\text { Vacuum } \\
\text { Residue }\end{array}$ & $\begin{array}{c}\text { Batch Type } \\
\text { Autoclave } \\
\text { Fitted with a Stirrer }\end{array}$ & $85.2 \%$ & [18] \\
\hline Fe-Char & $800{ }^{\circ} \mathrm{C}$ & N/A & Oily Sludge & $\begin{array}{l}\text { Two Stage Fixed- } \\
\text { Bed Reactor }\end{array}$ & $95.8 \%$ & [26] \\
\hline $\mathrm{NiK} / \mathrm{CeZr}-\mathrm{Al}$ & $500{ }^{\circ} \mathrm{C}$ & $\begin{array}{l}\text { Atmospheric } \\
\text { Pressure }\end{array}$ & $\begin{array}{l}\text { Vacuum } \\
\text { Residue }\end{array}$ & Fixed-Bed Reactor & $88.7 \%$ & {$[27]$} \\
\hline USY/ZSM-5 & $500{ }^{\circ} \mathrm{C}$ & N/A & Residue Oil & Fixed Fluid Bed & $76.11 \%$ & [28] \\
\hline \multirow{2}{*}{$\begin{array}{l}\text { Sandstone based } \\
\text { drill (Silica } \\
\text { Alumina) }\end{array}$} & \multirow{2}{*}{$420^{\circ} \mathrm{C}$} & \multirow{2}{*}{$\begin{array}{l}\text { Atmospheric } \\
\text { Pressure }\end{array}$} & $\begin{array}{l}\text { Vacuum } \\
\text { Residue }\end{array}$ & \multirow{2}{*}{ Batch Parr Reactor } & $77 \%$ & \multirow{2}{*}{ [29] } \\
\hline & & & $\begin{array}{l}\text { Atmospheric } \\
\text { Residue }\end{array}$ & & $62 \%$ & \\
\hline $\begin{array}{c}\text { Silica } \\
\text { Alumina/ } \beta \\
\text { Zeolite }\end{array}$ & $500{ }^{\circ} \mathrm{C}$ & $0,45 \mathrm{MPa}$ & $\begin{array}{l}\text { Vacuum Gas } \\
\text { Oil }\end{array}$ & $\begin{array}{l}\text { Curie Point } \\
\text { Pyrolyzer }\end{array}$ & $46 \%$ & {$[30]$} \\
\hline $\mathrm{Ca} / \mathrm{Al}$ & $650{ }^{\circ} \mathrm{C}$ & N/A & $\begin{array}{l}\text { Vacuum } \\
\text { Residue }\end{array}$ & $\begin{array}{l}\text { Fluidized Bed } \\
\text { Reactor }\end{array}$ & $97.4 \%$ & {$[31]$} \\
\hline
\end{tabular}

\section{Catalyst Regenerator Technology}

Table 3 shows the methods of regeneration process equipped with gas composition. In the catalyst regeneration of the RCC process that occurs in the regenerator, the aim is to reactivate the catalyst by removing coke attached to the surface of the catalyst, and regenerated by burning coke attached to the catalyst [32]. Conventionally, the spent FCC catalyst is reactivated via coke combustion in the fluidized bed regenerator. It will generate excessive heat in the system because of its high coke yield when treating heavy oil. External catalyst cooler or boiler should be applied to extract the heat and maintain the heat balance of the operation, which leads to a great waste of carbon resources and high $\mathrm{SO}_{\mathrm{x}}$ and $\mathrm{NO}_{\mathrm{x}}$ emissions during coke combustion. On the other hand, 
hydrogen is usually of great deficiency in the refinery, especially processing heavy oil into light oil products [33]. Based on Table 3 about the comparison of output gas composition in regeneration technology, the Oxy-Combustion method is profitable in the catalyst regeneration process. The basic concept is to use oxygen to burn coke contained in the catalyst which will produce lower emissions, and higher efficiency and produces high $\mathrm{CO}_{2}$ flow [34]. The feasibility of an oxy-combustion step for the catalyst regeneration has been studied with reference to a spent catalyst due to carbon deposition during the methane thermo-catalytic decomposition [35].

Table 3. Gas Composition of Regeneration Process

\begin{tabular}{|c|c|c|c|}
\hline Method & Gas Composition & \% Mol & Reference \\
\hline \multirow{4}{*}{ Oxy - Combustion } & $\mathrm{CO}_{2}$ & 94.5 & \multirow{4}{*}[36,37]{} \\
\hline & $\mathrm{O}_{2}$ & 3.1 & \\
\hline & $\mathrm{N}_{2}$ & 2.1 & \\
\hline & $\mathrm{CO}$ & 0.01 & \\
\hline \multirow{4}{*}{$\begin{array}{l}\text { Multi-Phase Particle-In- } \\
\text { Cell }\end{array}$} & $\mathrm{CO}_{2}$ & 12 & \multirow{4}{*}[38,39]{} \\
\hline & $\mathrm{O}_{2}$ & 4.4 & \\
\hline & $\mathrm{N}_{2}$ & 75.3 & \\
\hline & $\mathrm{CO}$ & 0.69 & \\
\hline \multirow{4}{*}{$\begin{array}{c}\text { FCC Alliance R2R Resid } \\
\text { FCC unit }\end{array}$} & $\mathrm{CO}_{2}$ & 7.2 & \multirow{4}{*}{ [40] } \\
\hline & $\mathrm{O}_{2}$ & 8.6 & \\
\hline & $\mathrm{N}_{2}$ & 74.8 & \\
\hline & $\mathrm{CO}$ & 3.6 & \\
\hline
\end{tabular}

\section{Conclusion}

One of fuel processing technology, namely the RCC unit, RCC unit is secondary processing that converts heavy fraction hydrocarbons into light fraction hydrocarbons with the help of the use of catalysts into high-value petroleum products such as naphtha, LPG, and Light Cycle Oil. The RCC unit has three main parts for this process, namely the riser, stripper, and regenerator. Based on the review of catalyst development in the RCC unit in this paper, important considerations for choosing a catalyst consists of catalysts must have a high tolerance to deposited metals, have high hydrothermal stability, suitable activities, high gasoline selectivity, and catalyst stability. $\mathrm{Ca} / \mathrm{Al}$ type Catalyst with Vacuum Residue feed on Fluidized Bed Reactor produces 97.4\% conversion. $\mathrm{Ca} / \mathrm{Al}$ type catalyst the most match for RCC unit, cause use feed from vacuum residue and have the high conversion although greater than Ni/Activated Carbon. Ni/Activated Carbon Type catalyst with oil sand Bitumen Clave feed on Auto Clave Reactor Batch Reactor produces 97.7\% conversion. The two types of catalysts are suitable for the RCC unit because they have the highest conversion with different feeds.

In addition, regeneration technology should be made based on the comparison of the output gas composition, and then the Oxy-Combustion method is profitable in the regeneration process of the catalyst because it uses oxygen to burn coke which will produce lower emissions, and higher efficiency and produces high $\mathrm{CO}_{2}$ flow

\section{Acknowledgment}

Thanks to the Chemical Engineering Department of the Universitas Ahmad Dahlan for facilitating us in the process of writing this journal.

\section{References}

[1] BP Energy, "BP Energy Outlook 2019 Edition," 2019. [Online]. Available: https://www.bp.com/en/global/corporate/energy-economics/energy-outlook/introduction.html 
[2] BPPT Outlook Energi Indonesia, “Outlook Energi Indonesia 2018,” 2018.

[3] Risdiyanta, R, "Mengenal Kilang Pengolahan Minyak Bumi (Refinery) di Indonesia," Swara Patra, 5(4), 2015

[4] G. R. K. Sung Won Kim, Jae Wook Shin, Ik Sang Yoo, Hun Sik Kang, and Sang Hoon Park, "Fluidization Technology for Stable Startup of Commercial FCC Unit," The $13^{\text {th }}$ International Conference on Fluidization - New Paradigm in Fluidization Engineering, 2010.

[5] K. A. Ehsan Amini, Alimorad Rashidi, Amirali Youzbashi, Mehran Rezaei, "Preparation of nanozeolitebased RFCC catalysts and evaluation of their catalytic performance in RFCC process," Journal of the Taiwan Institute of Chemical Engineers, vol. 100, pp.37-46, 2019.

[6] James G. Speight, "Catalytic Cracking Processes," Heavy Oil Recovery and Upgrading, p. 64, 2019.

[7] Vladimir Haensel, "Catalytic Cracking of Pure Hydrocarbons," In Advances in Catalysis (Vol. 3, pp. 179-197). Academic Press, 1951.

[8] F. Q. Min Wei, Wenli Du, Jun Hu, Meihong Wang, Xiaobo Luo, Minglei Yang, "Study on the integration of fluid catalytic cracking unit in refinery with solvent-based carbon capture through process simulation," Fuel, vol. 219, pp.364-374, 2018.

[9] A. S. a. Peter Deglmann, and Christian Lennartz, "Application of Quantum Calculations in the Chemical Industry_An Overview," International Journal of Quantum Chemistry, 115(3), pp.107-136, 2014.

[10] F. D.-C. Rolando Roque-Malherbe, "Calculation of the energy of adsorption of n-paraffins in nanoporous crystalline and ordered acid catalysts, and its relationship with the activation energy of the monomolecular catalytic cracking reaction," Journal of Molecular Catalysis A: Chemical, vol. 280(1-2), pp.194-202, 2008.

[11] E. I. Emiliya Ivanchina, Galina Nazarova, "Mathematical modeling of catalytic cracking riser reactor," Chemical Engineering Journal, vol. 329, p. 12, 2017.

[12] Fonseca, N., dos Santos, L.R.M., Cerqueira, H.S., Lemos, F., Ramôa-Ribeiro, F., Lam, Y.L. and de Almeida, M.B.B., "Olefins production from cracking of a Fischer-Tropsch naphtha," Fuel, vol. 95, pp.183-189, 2012.

[13] Andersson, S.I. and Myrstad, T., "Optimum Properties of RFCC catalysts," Preprints-American Chemical Society. Division of Petroleum Chemistry, 44(4), pp.495-496, 2001.

[14] Mario L. Occelli, "Recent Trends in Fluid Catalytic Cracking Technology," 1988.

[15] Sadeghbeigi R, "Fluid catalytic cracking handbook: an expert guide to the practical operation, design, and optimization of FCC units," $3^{\text {rd }}$ ed. London: Elsevier, 2012.

[16] Z. Z. Pusheng Liu, Mingjun Jia, Xionghou Gao, Jihong Yu, "ZSM-5 zeolites with different $\mathrm{SiO}_{2} / \mathrm{Al}_{2} \mathrm{O}_{3}$ ratios as fluid catalytic cracking catalyst additives for residue cracking," Chinese Journal of Catalysis, vol. 36(6), pp.806-812, 2015.

[17] S. J. A. Morteza Golmohammadi, Jafar Towfighi, "Catalytic cracking of heavy petroleum residue in supercritical water: study on the effect of different metal oxide nanoparticles," J. of Supercritical Fluids, 113, pp.136-143, 2016.

[18] C. N.-H. Hak Sung Lee, Thanh-Truc Pham, Eun Woo Shin, " $\mathrm{ZrO}_{2}$-impregnated red mud as a novel catalyst for steam catalytic cracking of vacuum residue," Fuel, vol. 165, pp.462-467, 2016.

[19] E. W. S. Chinh Nguyen-Huy, "Amelioration of catalytic activity in steam catalytic cracking of vacuum residue with $\mathrm{ZrO}_{2}$-impregnated macro-mesoporous red mud," Fuel, 179, pp.17-24, 2016.

[20] A. Akah, "Application of rare earth in fluid catalytic cracking: A review," JOURNAL OF RARE EARTHS, vol. 35, p. 941, 2017.

[21] F. E. T. Eduardo Falabella Sousa-Aguiar, Fatima Maria Zanon Zotin, "The role of rare earth elements in zeolites and cracking catalysts," Catalysis Today, 218, pp.115-122, 2013.

[22] Al-Absi, A.A., Aitani, A.M. and Al-Khattaf, S.S., "Thermal and catalytic cracking of whole crude oils at high severity," Journal of Analytical and Applied Pyrolysis, 145, p.104705, 2019. 
[23] P. P.-A. Fredy A. Cabrales-Navarro, "Catalytic Steam Cracking of a Deasphalted Vacuum Residue Using a Ni/K Ultradispersed Catalyst," energy \& fuel, 31(3), pp.3121-3131, 2017.

[24] C. N.-H. Do Thi Lien, Eun Woo Shin, "NiK/yCexZr1- $\mathrm{xO}_{2}$-macroporous $\mathrm{Al}_{2} \mathrm{O}_{3}$ catalysts for cracking of vacuum residual oil with steam," Applied Catalysis A: General, 525, pp.23-30, 2017.

[25] H. A. Xi-Kun Gai a, Peng Lua, Jian-Wei Mao, Yoshiharu Yoneyama, Cheng-Xue Lua, Rui-Qin Yang, Noritatsu Tsubaki, "Catalytic bitumen cracking in sub- and supercritical water," Fuel Processing Technology, 142, pp.315-318, 2016.

[26] Q. H. Bingcheng Lin, Yuxuan Yang, Yong Chi, "Preparation of Fe-char catalyst from tank cleaning oily sludge for the catalytic cracking of oily sludge," Journal of Analytical and Applied Pyrolysis, 139, pp.308-318, 2019.

[27] Nguyen-Huy, C. and Shin, E.W., "Oxidative cracking of vacuum residue with steam over NiK/CeZr-Al catalysts," Fuel, 192, pp.149-157, 2017.

[28] P. Liu, Ying Cui, Guangbi Gong, Xiaohui Du, Jianyu Wang, Xionghou Gao, Mingjun Jia, and Jihong $\mathrm{Yu}$, "Vanadium Contamination On The Stability Of Zeolit USY and Efficient Passivation by $\mathrm{La}_{2} \mathrm{O}_{3}$ For Cracking Residu Oil," Microporous and Mesoporous Materials, 279, pp.345-351, 2018.

[29] M. M. H. Thomas Kaminski, "Thermal cracking of atmospheric residue versus vacuum residue," Fuel Processing Technology, vol. 181, pp.331-339, 2018.

[30] T. N. Thanita Sonthisawate, Hiroyuki Nasu, Tadanori Hashimoto, Atsushi Ishihara, "Catalytic cracking reaction of vacuum gas oil and atmospheric residue by zeolite-containing microporous and mesoporous composites using Curie point pyrolyzer," Fuel Processing Technology, 142, pp.337-344, 2016.

[31] M. Y. Ruiyuan Tang, Kai Liu, Huafeng Li, Juntao Zhang, Yuanyu Tian, "Utilization of bifunctional catalyst for upgrading petroleum residue via cracking and gasification: Effect of catalysts," Journal of the Energy Institute, 92(6), pp.1936-194, 2018.

[32] L. Y. Hongwei Guan, Feifan Shen, Zhihuan Song, "Economic operation of a fluid catalytic cracking process using self-optimizing control and reconfiguration," Journal of the Taiwan Institute of Chemical Engineers, 96, pp.104-113, 2019.

[33] Zhang, Y., Sun, G., Gao, S. and Xu, G., "Regeneration Kinetics of Spent FCC Catalyst via Coke Gasification in a Micro Fluidized Bed," Procedia engineering, 102, pp.1758-176, 2015.

[34] Younes, M., Jamal, A., Niass, T., Levasseur, A., Stallmann, O. and Di Federico, G., "Oil Heavy Residues Oxy-combustion with $\mathrm{CO}_{2}$ Capture," Energy Procedia, vol. 114, p. 505-521, 2017.

[35] Ammendola, P., Chirone, R., Ruoppolo, G. and Russo, G., "Regeneration of spent catalysts in oxycombustion atmosphere," Experimental Thermal and Fluid Science, 34(3), pp.262-268, 2010.

[36] de Mello, L.F., Pimenta, R.D., Moure, G.T., Pravia, O.R., Gearhart, L., Milios, P.B. and Melien, T., "A technical and economical evaluation of $\mathrm{CO}_{2}$ capture from FCC units," Energy Procedia, 1(1), pp.117124, 2009.

[37] de Mello, L.F., Gobbo, R., Moure, G.T. and Miracca, I, "Oxy-Combustion Technology Development for Fluid Catalytic Crackers (FCC) - Large Pilot Scale Demonstration," Energy procedia, 37, pp.7815-7824, 2013.

[38] Berrouk, A.S., Huang, A., Bale, S., Thampi, P. and Nandakumar, K., "Numerical simulation of a commercial FCC regenerator using Multiphase 5 Particle-in-Cell methodology (MP-PIC)," Advanced Powder Technology, 28(11), pp.2947-2960, 2017.

[39] Singh, R. and Gbordzoe, E., "Modeling FCC spent catalyst regeneration with computational fluid dynamics," Powder Technology, 316, pp.560-568, 2016.

[40] Amblard, B., Singh, R., Gbordzoe, E. and Raynal, L., "CFD modeling of the coke combustion in an industrial FCC regenerator," Chemical Engineering Science, 170, pp.731-742, 2016. 